Ks. Paweł Podeszwa

Verbum Vitae 28 (2015) 319-344

\title{
SYNTAGMA „MIEĆ ŚWIADECTWO JEZUSA" W APOKALIPSIE JANOWEJ
}

\section{The Syntagma "have the testimony of Jesus" in the Apocalypse of John}

\begin{abstract}
The theme of testimony is one of the most important theological motifs in the final book of the New Testament, the Apocalypse of John. The noun "testimony" appears there nine times $(1: 2.9 ; 6: 9 ; 11: 7 ; 12: 11.17 ; 19: 10[\mathrm{x} 2] ; 20: 4)$, always in the singular form. The noun "testimony" is accompanied three times by the verb "have", with which it creates the syntagma "have the testimony" $(6: 9 ; 12: 17 ; 19: 10)$. This syntagma, according to some analysts, indicates "a deeper identity of the disciples" of Jesus. In the present article I suggest an analysis of the above-mentioned phrase, seeking to identify the essence of that deeper identity of Jesus' followers, which is expressed by the analyzed constituent segment. I begin with a few remarks about the etymology of the noun "testimony", understood as the memory of people and events. Next, I analyze the three fragments which feature the syntagma "have the testimony". From that background, I finally seek to answer the question of the sense of such an expression within the context of understanding the identity of Jesus' followers. The living memory of Jesus - kept, experienced and passed along - shapes the identity of Christ's followers. It looks back to the past, but at the same time is open to the present and, through hope, allows believers to await the future. In this way Jesus' followers become witnesses and prophets of Jesus in the modern world.
\end{abstract}


Keywords: Apocalypse, testimony, have the testimony, memory, Christian identity

Streszczenie: Temat świadectwa jest jednym w ważnych motywów teologicznych ostatniej księgi Nowego Testamentu, jaką stanowi Apokalipsa Janowa. Rzeczownik ,świadectwo" występuje w niej dziewięć razy $(1,2.9 ; 6,9 ; 11,7 ; 12,11.17 ; 19,10$ [x2]; 20,4), zawsze w liczbie pojedynczej. Trzykrotnie rzeczownikowi „świadectwo” towarzyszy czasownik „mieć”, z którym tworzy syntagmę „mieć świadectwo" $(6,9 ; 12,17 ; 19,10)$. Zdaniem niektórych komentatorów wskazuje ona na ,głębszą tożsamość uczniów" Jezusa. W niniejszym artykule proponuję analizę powyższego sformułowania, szukając odpowiedzi na pytanie o istotę owej pogłębionej tożsamości wyznawców Jezusa, którą wyraża omawiany związek wyrazowy. Rozpoczynam od kilku uwag na temat etymologii rzeczownika ,świadectwo” pojmowanego jako pamięć o osobach i wydarzeniach. Następnie analizuję trzy fragmenty, w których występuje syntagma „mieć świadectwo", aby w ostatnim punkcie rozważań szukać odpowiedzi na pytanie o sens tego wyrażenia w kontekście rozumienia tożsamości wyznawców Jezusa. Żywa pamięć o Jezusie, przechowywana, przeżywana i przekazywana, kształtuje tożsamość wyznawców Chrystusa, która powraca do przeszłości, ale jest jednocześnie otwarta na teraźniejszość oraz z nadzieją pozwala oczekiwać przyszłości. W ten sposób wyznawcy Jezusa stają się świadkami i prorokami Jezusa wobec współczesnego świata.

Słowa klucze: Apokalipsa, świadectwo, mieć świadectwo, pamięć, tożsamość chrześcijańska

Temat świadectwa jest jednym w ważnych motywów teologicznych ostatniej księgi Nowego Testamentu, jaką stanowi Apokalipsa Janowa ${ }^{1}$. Częstotliwość użycia samego rzeczownika ,świadectwo" ( $\mu \alpha \rho \tau u \rho i ́ \alpha)$ wskazuje, że jest to termin typowo Janowy, gdyż zastosowany trzydzieści siedem razy w Nowym Testamencie (Mk 3; Łk 1; J 14; Dz 1; 1 Tm 1; Tt 1; 1 J 6; 3 J 1; Ap 9)² aż trzydzieści razy wy-

${ }^{1}$ Zob. Podeszwa, Paschalna.

${ }^{2}$ Podobnie czasownik, ,świadczyć" ( $\left.\mu \alpha \rho \tau \nu \rho \in ́ \omega\right)$ jest typowo Janowy, ponieważ w Nowym Testamencie został użyty siedemdziesiąt sześć razy, 
stępuje w pismach Janowych: czternaście razy w Ewangelii Janowej (1,7.19; 3,11.32.33; 5,31.32.34.36; 8,13.14.17; $19,35 ; 21,24) ;$ w listach siedem razy (1 J 5,9[x3].10[x2].11 oraz $3 \mathrm{~J}$ 12) oraz dziewięć razy w Apokalipsie (1,2.9; 6,9; $11,7 ; 12,11.17 ; 19,10[\mathrm{x} 2] ; 20,4)^{3}$.

W księdze zamykającej kanon Nowego Testamentu rzeczownik ,świadectwo" używany jest zawsze w liczbie pojedynczej. Najczęściej spotykane wyrażenie to

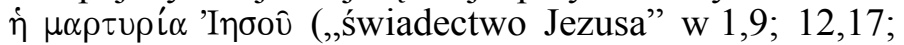
19,10[x2]; 20,4 i 6,9, gdzie imię Jezusa jest domyślne), ponadto na samym początku Księgi w 1,2 wspomniane zostaje „świadectwo Jezusa Chrystusa”, poświadczone przez Jana, natomiast w 11,7 mowa jest o ,ich świadectwie", w odniesieniu do Dwóch Świadków, a w 12,11 nawiązuje się do „słowa ich świadectwa”, czyli chrześcijan, którzy pokonali Szatana.

Trzykrotnie rzeczownikowi „świadectwo" towarzyszy czasownik „mieć”, z którym tworzy syntagmę „mieć świadectwo" $(6,9 ; 12,17 ; 19,10)$. Zdaniem niektórych komentatorów wskazuje ona na „głębszą tożsamość uczniów” Jezusa $^{4}$. W niniejszym artykule proponuję analizę powyższego sformułowania, szukając odpowiedzi na pytanie o istotę owej pogłębionej tożsamości wyznawców Jezusa, którą wyraża omawiany związek wyrazowy. Rozpoczynam od kilku uwag na temat etymologii rzeczownika ,świadectwo" pojmowanego jako pamięć o osobach i wydarze-

z czego czterdzieści siedem w pismach Janowych $(1,7.8 .15 .32 .34 ; 2,25$; 3,11.26.28.32; 4,39.44; 5,31.32[x2].33.36.37.39; 7,7; 8,13.14.18[x2]; 10,$25 ; 12,17 ; 13,21 ; 15,26.27 ; 18,23.37 ; 19,35 ; 21,24 ; 1 \mathrm{~J} 1,2 ; 4,14$; 5,6.7.9.10; 3 J 3,6.12[x2]; Ap 1,2; 22,16.18.20). Jeśli chodzi o występowanie innych słów etymologicznie podobnych, zob. zestawienie zaproponowane przez Donegani, A cause de la parole, 208. $\mathrm{Z}$ zestawienia wynika, że temat świadectwa jest charakterystyczny dla dzieła Łukaszowego oraz pism Janowych. Zob. także Beutler, Martyria, 170171. Zestawienie i krótka analiza występowania terminu ,świadectwo" w tekstach Nowego Testamentu, zob. Podeszwa, Paschalna, 65-80.

${ }^{3}$ Syntetyczne ujęcie problematyki świadectwa w tradycji Janowej, zob. Bianchi, „La testimonianza”, 119-137.

${ }^{4}$ Marino, Custodire, 123: „l'identità più profonda dei discepoli”. 
niach. Następnie przeanalizuję trzy fragmenty, w których występuje syntagma „mieć świadectwo”, aby w ostatnim punkcie rozważań szukać odpowiedzi na pytanie o sens tego wyrażenia w kontekście rozumienia tożsamości wyznawców Jezusa.

\section{1. ŚWIAdECTWO JAKO PAMIĘĆ}

Rzeczownik $\mu \alpha \rho \tau u \rho i ́ \alpha$ (,świadectwo"5) został prawdopodobnie utworzony od rzeczownika $\mu \alpha \dot{\rho} \tau \tau \varsigma^{6}$, który pochodzi od rdzenia indoeuropejskiego smer/mer, oznaczającego „mieć w pamięci, pamiętać, myśleć, przypominać sobie, przejmować się czymś"’ . Według H. Strathmanna rzeczownik $\mu \alpha \dot{\rho} \tau v \varsigma$ oznacza zatem ,tego, który ma coś w pamięci, przypomina sobie, ze swoich wspomnień czerpie poznanie jakieś rzeczywistości i dlatego może przekazać wiadomości na jej temat, staje się zatem świadkiem"». Mając na uwadze te pierwotne zależności etymologiczne, można sprecyzować znaczenie rzeczownika $\mu \alpha \rho \tau u \rho i ́ \alpha$ jako pamięć wynikającą z doświadczenia i refleksji, to znaczy odniesienia podmiotu do rzeczywistości przeżytej i zweryfikowanej (zapamiętanej), która nie może pozostać zapomniana. Takie doświadczenie jest przekazane innym,

\section{${ }^{5}$ Popowski, Wielki stownik, 378.}

${ }^{6}$ Tutaj zdania językoznawców są podzielone, czy rzeczownik został utworzony od rzeczownika $\mu \alpha \dot{\rho} \tau \tau$ c, czy raczej formy czasownikowej $\mu \alpha \rho \tau \nu \rho \in ́ \omega$. Niewątpliwie rzeczownik $\mu \alpha \rho \tau u \rho i ́ \alpha$, został utworzony przez dodanie typowej końcówki -í $\alpha$, która wskazuje na rzeczownik abstrakcyjny, używany często jako nomen actionis dla wyrażenia czynności dawania świadectwa oraz samego aktu świadectwa jako takiego. Czasami rozróżnienie tych dwóch odcieni znaczeniowych jest niemożliwe. Zob. Donegani, A cause de la parole, 54.

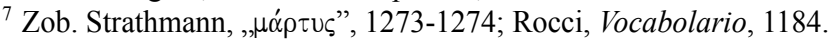
Zob. także Ernout - Meillet, Dictionnaire, 396; Boisacq, Dictionnaire, 612; Coenen, „Testimonianza”, 1857-1858.

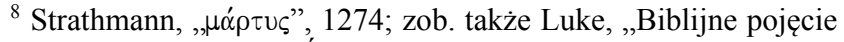
martyria”, 74; Mickiewicz, Świadkowie, 19-22; Kudasiewicz, „Jeruzalem", 131-134. 
a przedmiot doświadczenia zostaje wyeksponowany przez świadectwo. W ten sposób świadectwo ma swoje korzenie w doświadczeniu. Żyje dzięki pamięci o tym, co się wydarzyło. Stąd świadek ( $\mu \alpha$ $\rho \tau u \varsigma)$ to przekaziciel, dzięki pamięci którego pewne wydarzenia, rzeczywistości oraz osoby z przeszłości odżywają. Te informacje stają się obecne (aktualne) w teraźniejszości i mogą być przekazane innym ${ }^{9}$. Rzeczownik $\mu \alpha \rho \tau u \rho i ́ \alpha$ oznacza zatem ,rozważające i ponownie badające przypominanie, podnoszenie w swojej świadomości osobiście przeżytych wydarzeń i czegoś doświadczonego, co nie może zostać pominięte, zapomniane i jako takie powinno zostać przekazane innym"10.

Jak już wspomnieliśmy, w Apokalipsie rzeczownik ,świadectwo" pojawia się najczęściej w wyrażeniu „Świadectwo Jezusa" (1,9; 12,17; 19,10[x2]; 20,4 i 6,9). Studium tego sformułowania prowadzi do wniosku, że chodzi przede wszystkim o pamięć o Jezusie, która jest zachowywana i przekazywana przez wspólnotę Janową ${ }^{11}$. Charakterystyczne jest występowanie imienia Jezus, które odsyła do postaci historycznej Jezusa z Nazaretu ${ }^{12}$. W świetle 1,2, gdzie występuje ,świadectwo Jezusa Chrystusa” obok „słowa Bożego” interesujące nas wyrażenie jest syntetycznym określeniem całego objawienia, które pochodzi od Boga przez Jezusa Chrystusa ${ }^{13}$. Staje się ono synonimem Księgi Apokalipsy, zawierającej w sobie pa-

${ }^{9}$ Zob. Manzi, Memoria del Risorto, 22-23.

${ }^{10}$ Dziewulski, Świadectwo chrześcijańskie, 34.

${ }^{11}$ Podeszwa, Paschalna, passim.

${ }^{12}$ Zob. Malina, „Imię «Jezus»”, 243. Autor zwraca uwagę, że imię Jezus bez dodatkowych określeń pojawia się najczęściej w księgach narracyjnych, które koncentrują się na Jego ziemskim życiu i zawierają wypowiedzi odnoszące się wprost do tego okresu.

${ }^{13}$ Zdaniem D. Koteckiego, Jezus a Bóg Izraela, 43, na obie syntagmy „Słowo Boga” i ,świadectwo Jezusa Chrystusa” można ,spojrzeć w kluczu kontynuacyjno-wypełnieniowym. W wyrażeniu „Słowo Boga” mogłoby chodzić o objawienie zawarte w Starym Testamencie, po którym następuje objawienie pochodzące od Jezusa Chrystusa, które jest pełnią objawienia Boga". Jednak Jezus nie jest rozumiany jedynie jako prorok Boga, ale jako ktoś równy Bogu. Byłby to jeden z pierwszych 
mięć o Jezusie Chrystusie, która jako objawienie - proroctwo zostaje powierzona wspólnocie Janowej, aby słuchała i strzegła jej wiernie $(1,3 ; 22,7)$. Chodzi zawsze o jedyne świadectwo Jezusa (w 1,5 nazwany jest, ,Wiernym Swiadkiem”), którego On jest źródłem i przekazicielem (znaczenie podmiotowe) i dotyczy samego Jezusa i wydarzeń z Jego życia, zwłaszcza misterium paschalnego (znaczenie przedmiotowe). Skoro zostało ono przekazane wspólnocie, to nie dziwi fakt, że aż trzykrotnie chrześcijanie zostają określeni jako ci, którzy „mają świadectwo (Jezusa)”"14.

\section{Analiza tekstów Z Syntagmą "MIEĆ ŚWIADECTWO JEZUSA"}

\section{„Dusze zabitych z powodu słowa Bożego i świadec- twa [Jezusa], jakie mieli” $(6,9)$}

Pierwszy raz syntagma „mieć świadectwo” pojawia się w 6,9, rozpoczynającym opowiadanie o otwarciu piątej pieczęci. Fragment ten należy do dłuższej jednostki literackiej, obejmującej opis wydarzeń, które są konsekwencją łamania kolejnych siedmiu pieczęci $(6,1-8,1)$. Kiedy Baranek otworzył piątą pieczęć, Jan zobaczył „dusze zabitych z powodu słowa Bożego i świadectwa, jakie mieli". Powyższe sformułowanie przypomina z jednej strony to, znajdujące się w 1,9, dzięki identycznej konstrukcji gramatycznej z przyimkiem wyrażającym przyczynę ,,z powodu”, oraz sformułowanie ,słowo Boga”. Z drugiej jednak strony, dostrzegamy różnicę polegającą na tym, że tym razem jest mowa o ,świadectwie", które nie zostaje określone jako „Jezusa”. Zdaniem niektórych komentatorów można jednak uznać, że to dopowiedzenie jest domyślne. Takie przekonanie opiera się na wspomnianym paralelizmie z 1,9, a także z 20,4, w którym powracają nie tylko

elementów wskazujący na charakterystyczny dla Apokalipsy ścisły związek teologii z chrystologią.

${ }^{14}$ Podeszwa, Paschalna, 95-131. 
wyrażenia: „słowo Boga” oraz ,świadectwo Jezusa”, ale także jest mowa o „duszach ściętych”, co jest paralelne do wyrażenia „dusze zabitych” w 6,9. Jak zauważa I. Donegani, słuchacz albo czytelnik Apokalipsy, zaznajomiony z księgą, gdy napotyka wyrażenie ,świadectwo”, spontanicznie łączy je ze ,świadectwem Jezusa"15. Możemy zatem przyjąć, że także w 6,9 mamy do czynienia ze „świadectwem Jezusa”, czyli pamięcią o Jezusie, która podobnie jak w 1,9 wiernie zachowywana i przekazywana staje się przyczyną prześladowania chrześcijan.

W 6,9 ,świadectwo" zostaje zdefiniowane jako to, które zabici ,„posiadali (mieli)”. Niektóre przekłady interpretują to wyrażenie jako świadectwo złożone Jezusowi (znaczenie przedmiotowe) ${ }^{16}$. Kim są ,zabici” w 6,9? Chodzi o męczenników, którzy poprzez swoją śmierć złączyli się z losem samego Jezusa. Określeni zostali jako ,zabici”. Użyty czasownik ,zabijać” występuje kilkakrotnie w odniesieniu do ,zabitego Baranka” $(5,6.9 .12$; 13,8) i Jego naśladowców $(18,24)$. Zabici to ci, którzy oddali życie z powodu przynależności do Jezusa i w ten sposób złączyli swój los z losem ,zabitego Baranka”. Ich uczestnictwo w śmierci Baranka pozwala także mieć udział w Jego zwycięstwie, co stanowi fundamentalny element tożsamości chrześcijańskiej ${ }^{17}$. Kiedy mowa o zabitych z pewnością chodzi o prześladowania i męczeńską śmierć wyznawców Jezusa. Komentatorzy nie są zgodni, o jakie prześladowania mogłoby chodzić. Jedni uważają, że mamy tutaj aluzję do prześladowań chrześcijan za Nerona ${ }^{18}$ lub bliżej nieokreślonych prześladowań lokalnych w Azji ${ }^{19}$ bądź

15 Donegani, A cause de la parole, 363, podobnie Segalla, „La memoria", 133; Prigent, L'Apocalypse, 210.

16 Biblia Paulistów (ad loc.) tłumaczy ,,z powodu słowa Bożego i danego świadectwa”; Pytel, Apokalipsa, 30: ,z powodu Słowa Bożego i świadectwa, które Mu złożyli".

17 Zob. Beale, The Book of Revelation, 392.

18 Zob. Prigent, L'Apocalypse, 210; Aune, Revelation 6-16, 406.

19 Zob. Biguzzi, ,John on Patmos”, 212-214. 
męczenników Starego Przymierza ${ }^{20}$. Niektórzy zwracają także uwagę na fakt, że w tekście brakuje odniesienia do konkretnego miejsca prześladowań, co pozwala traktować je jako pewne uogólnienie: chodziłoby zatem o wszelki rodzaj ucisków i prześladowań ze względu na Jezusa ${ }^{21}$.

Zabici, czyli męczennicy, oddali swe życie, ponieważ stali się ,posiadającymi” świadectwo Jezusa, otrzymane od Niego. Kolejny raz zostaje podkreślona idea jedynego świadectwa Jezusa, którego On jest źródłem i przekazicielem (znaczenie podmiotowe) i które dotyczy samego Jezusa i wydarzeń z Jego życia (znaczenie przedmiotowe). Uczniowie Jezusa ,posiadają" Jego świadectwo. W Nowym Testamencie syntagma „mieć świadectwo” pojawia się trzy razy w J 5,36 i 1 Tm 3,7 i $1 \mathrm{~J} 5,10$. W pierwszym tekście jest mowa o świadectwie Jezusa większym od świadectwa, jakie dał Jan Chrzciciel. Natomiast w $1 \mathrm{Tm}$ 3,7 chodzi o posiadanie dobrej opinii, którą powinien cieszyć się kandydat na biskupa. Według $1 \mathrm{~J}$ 5,10 ,kto wierzy w Syna Bożego, ten ma w sobie świadectwo Boga".

Czasownik ,mieć” występuje często w Nowym Testamencie, a zwłaszcza w tradycji Janowej ${ }^{22}$. W Apokalipsie spotykamy go sto razy, zwłaszcza w opisach wizji. Jest stosowany nie tyle w znaczeniu pasywnego posiadania (kiedyś uczniowie otrzymali „świadectwo” od Chrystu-

${ }^{20}$ Zob. Feuillet, „Les martyrs”, 189-207. Zdaniem autora chodzi o męczenników Starego Przymierza, ponieważ w tekście i całym kontekście brakuje bezpośredniego odniesienia chrystologicznego. Według Prigenta (L'Apocalypse, 210) chodzi raczej o męczenników chrześcijańskich, bo odniesienie do Jezusa jest obecne przez użycie właśnie terminu ,świadectwo (Jezusa)", co jednak nie wyklucza definitywnie męczenników Pierwszego Przymierza.

${ }^{21}$ Le Grys, „Conflict”, 76-80, uważa, że konflikty społeczne, z jakimi borykała się wspólnota chrześcijańska, były przedstawiane jako prześladowania i dlatego poza wygnaniem Jana na Patmos i męczeństwem Antypasa są uogólnieniami. Przeciwna opinia, por. Biguzzi, L'Apocalisse, 94.

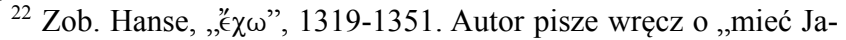
nowym” (,avere giovanneo”), 1324, 134-1347, które wyraża Janowe przekonanie, że chrześcijanie posiadają już zbawienie i życie wieczne. 
$\mathrm{sa}^{23}$ ), ile w znaczeniu aktywnym, ponieważ otrzymali, przyjęli, zaakceptowali dla siebie i ono stało się istotnym elementem ich egzystencji, co ostatecznie prowadzi do konieczności dawania takiego samego świadectwa ${ }^{24}$. Pamięć o Jezusie stała się zasadą życia chrześcijan, a wierność tej pamięci prowadzi do składania świadectwa, także przez męczeńską śmierć. Pamięć otrzymana, zachowywana, przeżywana i przekazywana stała się skarbem, którego trzeba było strzec nawet za cenę własnego życia. W takim znaczeniu sformułowanie ,zabity z powodu posiadania świadectwa Jezusa" zbliża nas do rozumienia świadectwa jako męczeństwa, a świadka jako męczennika ${ }^{25}$. Myśl ta zostanie rozwinięta $\mathrm{w}$ następnym tekście, w którym występuje wyrażenie „mieć świadectwo Jezusa”.

${ }^{23}$ Zob. Aune, Revelation 6-16, 406.

${ }^{24}$ Zob. Prigent, L'Apocalypse, 210.

${ }^{25}$ M. Wojciechowski (Apokalipsa, 143) pisze o terminie „świadek”. Uważa on, że określenie to nie musi oznaczać męczennika w sensie ścisłym, ale jest to niewątpliwie ,wczesna zapowiedź typowego dla późniejszego chrześcijaństwa użycia sądowego terminu «świadek» (gr. martys) na oznaczenie męczennika. Podobna sytuacja byłaby w przypadku rzeczownika ,świadectwo".

Na temat ewolucji semantycznej rzeczownika ,świadek” zob.

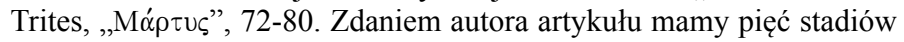
rozwoju znaczenia semantycznego terminu ,świadek”: 1) początkowo termin oznaczał świadka zeznającego przed trybunałem bez żadnej groźby kary śmierci; 2) oznaczał osobę, która składała świadectwo wiary wobec sądu i za nie była skazywana na karę śmierci; 3 ) śmierć jest traktowana jako część świadectwa; 4) termin „świadek” staje się synonimem „męczennika”, gdzie idea śmierci przewyższa wszelką inną koncepcję, choć ważne jest jeszcze pojęcie świadectwa, które nie jest pozbawione wartości; 5) pierwsze znaczenie zanika, ale „świadek” zaczyna oznaczać tylko „męczennika” (s. 72-73). Po analizie występowania terminu w Apokalipsie autor dochodzi do wniosku, że w księdze semantyczne znaczenie terminu ,świadek" nie dochodzi do czwartego i piątek stadium rozwoju (s. 80). Jednak według D.E. Aune'a (Revelation 1-5, 185): „However, while this development seems logical enough, semantic development is rarely so neat". 


\section{„Ci, którzy przestrzegają przykazań Bożych i mają świadectwo Jezusa" $(12,17)$}

Kolejny raz interesująca nas syntagma pojawia się w opisie walki Smoka Szatana, nieprzyjaciela Boga, z potomstwem „Niewiasty obleczonej w słońce” $(1,12)$. Jest ona symbolem Kościoła ${ }^{26}$, który jako kontynuacja ludu Bożego Starego Przymierza rodzi w bólach Chrystusa, to znaczy komunikuje Go innym, wzmacnia w historii wartości Jego zmartwychwstania poprzez świadectwo prorockie ${ }^{27}$.

Smok, który nie zdołał pokonać Niewiasty Kościoła, wpada $\mathrm{w}$ gniew ${ }^{28}(12,17 \mathrm{a})$ i rozpoczyna walkę z resztą Jej potomstwa ${ }^{29}$. Skoro nie może pokonać Niewiasty, rozpoczyna walkę z chrześcijanami, których zrodziła Niewiasta. Wyznawcy Jezusa są scharakteryzowani jako ci, „którzy strzegą przykazań Boga i posiadają świadectwo Jezusa”. Powraca zatem typowy paralelizm w używanym przez Jana wyrażeniu. Tym razem jednak ,świadectwo Jezusa" jest paralelne do „przykazań Boga”, a nie „słowa Bożego”, jak w $1,2.9 ; 20,4$. W ten sposób chrześcijanie są tymi, którzy łączą w sobie Torę ${ }^{30}$ i Ewangelię ${ }^{31}$, bo dla Jana Kościół

${ }^{26} \mathrm{Na}$ temat interpretacji rozdziału dwunastego Apokalipsy istnieje bardzo bogata literatura, zob. Stefaniak, Interpretacja; Prigent, Apocalypse 12; Muszyński, „Znak niewiasty”, 115-127; Sieg, ,Niewiasta” $i$,Syn”, 48-76; Farkaš, La „Donna”, 11-171; Przyjęcie interpretacji kolektywnej (Kościół czy nawet Lud Boży obu Testamentów) nie wyklucza interpretacji maryjnej Niewiasty apokaliptycznej. Mamy bowiem do czynienia $\mathrm{z}$ wielopłaszczyznowym symbolem, zgodnie także z konwencją gatunku literackiego Apokalipsy, zob. Muszyński, „Znak niewiasty”, 115; Oczachowski, „Dziecię”, 307-308.

${ }^{27}$ Zob. Kotecki, Duch Święty, 57-58.

${ }^{28} \mathrm{Na}$ temat gniewu jako motywu prześladowania i męczeństwa, zob. Smalley, The Revelation, 333 oraz Aune, Revelation 6-16, 707-708.

${ }^{29}$ Według Prigenta (L'Apocalypse, 306) możemy tutaj widzieć wyraźną aluzję do Rdz 3,15: nadszedł czas, że potomstwo Niewiasty jest wezwane do zwycięskiej walki z wężem.

${ }^{30} \mathrm{Na}$ temat przykazań Boga i Tory zob. ekskurs poświęcony tej problematyce: Aune, Revelation 6-16, 710-712.

${ }^{31}$ Beale, The Book, 766. Komentując tekst 14,12, interpretuje wyrażenie ,wiara od Jezusa” (dopełniacz podmiotowy) jako paralelne do 
to jeden Lud Boży, który składa się z dwunastu pokoleń Izraela i dwunastu apostołów Baranka ${ }^{32}$.

Typowo Janowe wyrażenie ,przykazania Boże” odnajdujemy często w Ewangelii oraz w Pierwszym Liście św. Jana. W czwartej Ewangelii jest mowa o „moich przykazaniach" w odniesieniu do Chrystusa (14,15.21; $15,10.12)$ lub o ,przykazaniach mojego Ojca” $(15,10)$. Natomiast w Pierwszym Liście św. Jana następuje pewnego rodzaju „teologizacja” wyrażenia, które odnosi się w liczbie mnogiej do Boga (2,3 - choć tutaj byłoby możliwe odniesienie bądź do Boga, bądź do Jezusa; 3,22.24; $5,2.3$ [x2]) oraz w liczbie pojedynczej $(3,23$ - inaczej niż w Ewangelii, w której mowa o przykazaniu Jezusa $13,34)$. Wyrażenie to $\mathrm{w}$ odniesieniu do Jezusa jest zatem synonimem ,Jego nauczania i streszcza w sobie tradycję parenetyczną Jezusa", szczególnie obecną w mowie pożegnalnej (J 13-17) $)^{33}$. Według 12,49-50 słowo Jezusa jest poleceniem Ojca, Jego przykazaniem ,nie przemawiałem bowiem sam od siebie, ponieważ Ojciec, który Mnie posłał, polecił Mi, co mam mówić i czego mam uczyć. A wiem, że Jego polecenie jest życiem wiecznym. Stąd też Ja głoszę tak, jak mi nakazał Ojciec. Właśnie tak uczę". Przykazanie Boga oznacza tutaj całe dzieło Syna ${ }^{34}$, które jest mówieniem i nauczaniem o Bogu. Jego życie przekazuje słowo samego Boga. Słowa Jezusa są zatem równoznaczne $\mathrm{z}$,"przykazaniami Boga" ${ }^{35}$. Potwierdza to także $1 \mathrm{~J} 2,3.5$, w których istnieje paralelizm między zachowywaniem przykazań a zachowywaniem Jego słowa. W takim sensie wyrażenie ,przykazania Boga” zostaje przejęte przez Apokalipsę, w której występuje jeszcze jeden raz w 14,12, kiedy mowa jest o ,wytrwałości świętych, którzy przestrzegają przykazań Boga i wiary Jezusa".

„przykazania Boga” i odnoszące się do ,the objective gospel traditions having their origin in Jesus".

${ }^{32}$ Zob. Bonsirven, L'Apocalypse, 214; Contreras Molina, ,La mujer ", 374 .

${ }^{33}$ Segalla, „La memoria simbolica”, 133.

${ }^{34}$ Zob. Léon-Dufour, Lecture, II 497.

${ }^{35}$ Zob. Vos, The Synoptic, 203. 
W ten sposób Apokalipsa łączy ze sobą typowe znaczenie chrystologiczne obecne w czwartej Ewangelii, w której była mowa o przykazaniach Jezusa z perspektywą teologiczną charakterystyczną dla Pierwszego Listu św. Jana. Wyrażenie ,przykazania Boga” zostaje wyjaśnione i doprecyzowane przez paralelne „świadectwo Jezusa", które określa jego zawartość. Uczniowie strzegą „przykazań Boga”, znajdujących swoje wypełnienie eschatologiczne w ,świadectwie Jezusa”, które jest teraz w posiadaniu uczniów Jezusa. Jest zatem charakterystyczne dla Apokalipsy, że „przykazania Boga” zostają wspomniane zawsze w kontekście chrystologicznym jako odniesienie do Jezusa historycznego ${ }^{36}$ (w 14,12 wyrażenie jest paralelne do „wiary Jezusa").

Idea posiadania „świadectwa Jezusa” nawiązuje wyraźnie do 6,9. Tym razem wyraźnie mowa o świadectwie Jezusa. W Apokalipsie imię Jezus występuje czternaście razy: dziewięć razy samodzielnie $(1,9[\mathrm{x} 2] ; 12,17 ; 14,12$; $17,6 ; 19,10[\mathrm{x} 2] ; 20,4 ; 22,16)$, trzy razy połączone $\mathrm{z}$, ,Chrystus”, zawsze w prologu Księgi $(1,1.2 .5)$ i dwa razy z „Panem" w zakończeniu Apokalipsy $(22,20.21)$. Już sama statystyka występowania imienia Jezus może wskazywać, że autor interesuje się Jezusem ziemskim i historycznymi wydarzeniami z Jego życia ${ }^{37}$. Tak rozumiane, ,świadectwo Jezusa", jako pamięć o Nim, jest w posiadaniu Jego wyznawców. Podobnie jak w poprzednim tekście $(6,9)$ chodzi o posiadanie aktywne, to znaczy kształtujące życie człowieka, który otrzymał ,świadectwo"; tak przyjęta pamięć o Jezusie i wierność tej pamięci prowadzi wyznawcę do złożenia świadectwa (także w sensie męczeństwa). Użyty czasownik ,mieć”, który jest paralelny do czasownika „strzec”, wyraża ideę posiadania, to znaczy silnego przywiązania, trzymania się, zachowywania z siłą i stałością. Chodzi ciągle o świadectwo Jezusa, będące pamięcią o Je-

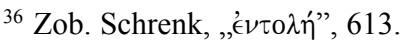

${ }^{37} \mathrm{Na}$ temat historycznego profilu ,świadectwa o Jezusie" zob. Podeszwa, Paschalna, 329-332: „Obejmuje ona pamięć o Jezusie, który narodził się, umarł i zmartwychwstał" (329). 
zusie historycznym. To konkretne doświadczenie historyczne kształtuje wyznawcę Jezusa. To ono jest przyczyną cierpienia i męczeństwa Jego uczniów. Kiedy powstaje Apokalipsa, to świadectwo Jezusa przybiera już konkretną formę, jest przekazywane poszczególnym wspólnotom bądź w formie ustnej, bądź pisemnej. Odczytywane i przyjmowane, szczególnie w kontekście zgromadzenia liturgicznego, zostaje przyjęte „w posiadanie” i stąd chrześcijanie mogą być określeni jako ci, „którzy posiadają świadectwo Jezusa" ${ }^{38}$. To jest charakterystyczny element ich tożsamości jako uczniów Jezusa. Użyte imiesłowy czasu teraźniejszego „przestrzegający” oraz „posiadający” podkreślają ideę trwania w czasie. Biorąc pod uwagę wspomniany wcześniej paralelizm z 14,12, w którym mowa o „wytrwałości świętych, którzy strzegą przykazań Boga i wiary Jezusa” oraz rozumiejąc „,wiarę Jezusa” jako „wierność Jezusa" ${ }^{39}$, można powiedzieć, że wspólnota pozostaje wierna Jezusowi, ponieważ otrzymała i potrafiła zachować przykład wierności Jezusa historycznego. Wierność ta stała się fundamentem jej tożsamości oraz egzystencji. Wyrażenie „wierność Jezusa” jest paralelne semantycznie do „świadectwa Jezusa”, oznaczającego pamięć o Jezusie, zawierającej szereg odniesień do Jego wytrwałości i wierności, najpełniej objawionych w misterium paschalnym. To wspomnienie kształtuje wierność wspólnoty oraz pozwala mocno trwać przy Chrystusie w momentach próby i prześladowania. Zarówno jedno, jak i drugie określenie konfrontuje zatem wspólnotę z Jezusem historycznym, aby dodać otuchy do walki z mocami szatańskimi ${ }^{40}$. Tak jak wspólnota ma zachowywać i praktykować przykazania Boga, tak również w identyczny sposób ma zachowywać

${ }^{38}$ Zob. Mickiewicz, Świadkowie, 304.

${ }^{39}$ Zob. Marino, Custodire, 145. Beale (The Book, 766) traktuje dopełniacz jako ,a genitive of source” i proponuje przekład ,wiara od Jezusa".

${ }^{40}$ Według D. Koteckiego (Duch Święty, 454): „,wyrażenie «wiara Jezusa» może być potraktowane na równi z określeniem Jezusa jako «świadka, tego wiernego, pierworodnego spośród umarłych» (Ap 1,5)". 
i praktykować „wierność Jezusa”41, będącą Jego świadectwem. Kościół posiada nie tylko „,́siadectwo Jezusa”, ale jest w aktywnym posiadaniu także ,wierności Jezusa”, która ma istotny wpływ na egzystencję wspólnoty.

\section{$(19,10)$ \\ „Twoi bracia, którzy mają świadectwo Jezusa}

Ostatnie miejsce, w którym występuje interesujące nas wyrażenie, to werset 19,10, stanowiący wraz z 19,9 przejście między Wielką Doksologią Apokalipsy $(19,1-8)$, będącą celebracją eschatologicznego zwycięstwa Boga, a wizją osądu dwóch Bestii, Smoka i śmierci $(19,11-21,8)$. Anioł nazywający siebie „współsługą” Jana i jego braci zwraca się do wizjonera i precyzuje, kim są jego bracia, określając ich jako tych, „którzy posiadają świadectwo Jezusa". Formuła jest identyczna z tą z 12,17 i na podstawie paralelizmu także z 6,9 wyrażenie to odnosi się do wszystkich chrześcijan ${ }^{42}$ posiadających ,świadectwo Jezusa", czyli pamięć o Jezusie historycznym ${ }^{43}$, którą przyjęli, strzegą jej i uczynili z niej fundament swojego chrześcijańskiego życia. Chodzi tutaj przede wszystkim o ,świadectwo Jezusa" rozumiane podmiotowo, czyli świadectwo samego Jezusa od Niego pochodzące, a nie tylko świadectwo dane Jezusowi ${ }^{44}$. Takie rozumienie, które akcentuje znaczenie podmiotowe dopełniacza, jest także - zdaniem G.B. Cairda - potwierdzone przez dwa określenia, zastosowane w odniesieniu do samego Jezusa - „Wierny Świadek” $(1,5)$ i „Świadek Wierny i Prawdziwy” $(3,14)$, oraz pojawiające się w bliskim kontekście w 19,11 określenie: Jeździec na białym koniu, który symbolizuje Chrystusa

${ }^{41} \mathrm{Na}$ temat użycia czasownika ,zachowywać” w połączeniu z „wiarą”, zob. Aune, Revelation 6-16, 837-838.

42 Zob. Lampe, „The Testimony”, 254. Autor uważa, że chodzi tutaj o cały lud chrześcijański.

${ }^{43}$ Zob. Aune, Revelation 17-22, 1038-1039.

${ }^{44}$ Zob. Charles, A Critical and Exegetical, II, 130, wg którego ze względu na obecność spójnika wyjaśniającego dopełniacz należy rozumieć jako przedmiotowy „the witness to Jesus”. 
zmartwychwstałego, jest tu opisany jako ,Wierny i Prawdziwy"45. Chodzi zatem o świadectwo Jezusa, będące w posiadaniu wspólnoty, która przekazuje je światu jako świadectwo o Jezusie.

W świetle paralelizmu do 22,9: ,bracia, którzy posiadają świadectwo Jezusa” to „,ci, którzy strzegą słów tej księgi". A zatem posiadanie świadectwa jest nierozerwalnie związane ze strzeżeniem słów Księgi Apokalipsy. Warto jeszcze zwrócić uwagę na użycie tego samego czasownika ,zachowywać”, jak w przypadku ,zachowywania przykazań Boga" w 12,17 i 14,12. Mamy więc trzy paralelne określenia: ,świadectwo Jezusa”, ,przykazania Boga” i „słowa księgi”, które zostają powierzone wspólnocie i są w „,czynnym” posiadaniu uczniów Jezusa, to znaczy kształtują ich tożsamość i sposób życia w konkretnej sytuacji egzystencjalnej wspólnoty.

Na podstawie tego samego paralelizmu do 22,9 można by przyjąć, że chodzi tylko o szczególną grupę braci Jana, którymi są ,,bracia prorocy”, bo w 22,9 zostali oni właśnie w ten sposób określeni. Bracia prorocy byliby szczególnymi ,posiadaczami” 'świadectwa Jezusa ${ }^{46}$, a także „stróżami" słów księgi. Chodziłoby niewątpliwie o proroków współczesnych Janowi, co podkreślałoby podwójne użycie imiesłowów czasu teraźniejszego. Do nich należy także sam Jan, który został zaliczony do „braci proroków”, choć sama księga nigdy nie określa go tym słowem wprost. Kim byli wspomniani bracia prorocy?

Rzeczownik ,prorok" pojawia się osiem razy w Apokalipsie i zawsze występuje w liczbie mnogiej (10,7; $11,10.18 ; 16,6 ; 18,20.24 ; 22,6.9)$. Najczęściej prorocy zostają wymienieni wraz ze świętymi (16,6 i 18,24), ze świętymi i bojącymi się imienia Boga $(11,18)$, ze świętymi i apostołami $(18,20)$, natomiast w 10,7 nazwani są

45 Zob. Caird, A Commentary, 237-238, zob. także Zahn, Die Offenbarung, 584; Vos, The Synoptic Traditions, 204-205; zob. także Moriconi, Lo Spirito, 80-81.

46 D. Kotecki (Duch Święty, 430) uważa, że określenie ,,prorocy” w 22,9 zastępuje wyrażenie ,mający świadectwo Jezusa” w 19,10; podobnie Moriconi, Lo Spirito, 82. 
sługami Boga, zaś w 22,6 wymienieni obok sług. Tylko w dwóch przypadkach $(11,10$ i 22,9$)$ jest mowa o prorokach bez wymieniania innych grup chrześcijan. Według powszechnie przyjmowanej opinii egzegetów rzeczownik ,prorocy" może mieć podwójne odniesienie: albo do szczególnej grupy osób obdarzonych charyzmatem proroctwa ${ }^{47}$, albo do chrześcijan w ogólności ${ }^{48}$. To drugie przekonanie wydaje się nam bardziej słuszne. Wskazuje na to użycie rzeczownika ,prorocy” jako paralelnego określenia zestawionego z innymi stosowanymi do chrześcijan, szczególnie paralelizm synonimiczny ze ,świętymi” i „bojącymi się imienia Boga" $(11,18 ; 16,6 ; 18,24)^{49}$. Ponadto skoro „bracia prorocy” są w posiadaniu świadectwa Jezusa, a wcześniejsze teksty wskazują jednoznacznie, że świadectwo Jezusa przynależy do chrześcijan w ogólności $(12,17$ i 6,9 ; także 20,4), a nie tylko do specjalnej grupy uczniów Jezusa, to można wnioskować, że określenie „bracia prorocy”, obejmujące także samego Jana, odnosi się do wszystkich uczniów Jezusa ${ }^{50}$. To spostrzeżenie wpisywałoby się dobrze w kontekst księgi, tym bardziej że w Apokalipsie cały Kościół jest widziany jako prorocki, co potwierdza także jedna $\mathrm{z}$ możliwych interpretacji dwóch świadków w Ap 11,1-13, symbolizujących Ko-

${ }^{47}$ Zob. Hill, „Prophecy and Prophets”, 401-417; Aune, „The Social Matrix”, 16-32; tenże, „The Prophetic Circle”, 103-116; Biguzzi, „Spirito e profezia", 503-522; Contreras Molina, El Espiritu, 140.

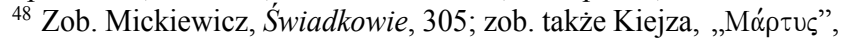
88-94; szczegółowa dyskusja na temat znaczenia określenia „bracia prorocy", zob. Kotecki, Duch Święty, 430-443.

${ }^{49}$ Zob. Mickiewicz, Świadkowie, 305.

${ }^{50}$ Takie rozumienie terminu nie wyklucza jednoznacznie istnienia pewnych osób, które miały konkretny charyzmat prorocki, o czym mówią niektóre teksty Pawłowe, szczególnie 1 Kor 11,4-5 oraz 14,29-33. Zdaniem niektórych komentatorów mogłoby to wskazywać także na pewną grupę prorocką zebraną wokół Jana na wzór grup prorockich w starożytnym Izraelu skupionych wokół proroków (1 Sm 10,12; $1 \mathrm{Krl}$ 20,35; $2 \mathrm{Krl}$ 2,3.5.7.12.15; 4,1.38; 5,22; 6,1; 9,1). Uczniów prorockich wspomina także Iz 8,16-18. Szeroko ten problem omawia Schüssler Fiorenza, „Apokalypsis and Propheteia”, 105-128. 
ściół jako społeczność, która kontynuuje misję prorocką Starego Testamentu pod natchnieniem Ducha Swiętego ${ }^{51}$. Taka interpretacja jest także potwierdzona przez drugą część omawianego wersetu, w którym mowa jest o tym, że „świadectwem Jezusa jest Duch proroctwa”. Jeśli słowa i czyny Jezusa historycznego stanowią Jego świadectwo, a ono jest przypominane i aktualizowane przez Ducha Świętego, który kontynuuje objawienie Jezusa, to „świadectwo Jezusa” staje się równoznaczne z „Duchem proroctwa”. Mamy zatem tożsamość między dwoma pojęciami: dzieło Jezusa i Jego świadectwo jest proklamowane i uobecniane dla wszystkich przez Ducha Świętego. W ten sposób świadectwo ziemskie Jezusa zostaje złączone ze świadectwem pneumatycznym o Jezusie pod natchnieniem Ducha Świętego ${ }^{52}$. Połączenie świadectwa z proroctwem pozwala sytuować świadectwo chrześcijańskie o Jezusie także w perspektywie męczeństwa, kiedy napotka ono opór świata przeciwnego Bogu i będzie się domagać od wyznawców Jezusa zdecydowanej postawy, nawet za cenę życia ${ }^{53}$. W ten sposób chrześcijanin staje się świadkiem, prorokiem i męczennikiem zarazem ${ }^{54}$, mającym pełen udział w zwycięstwie Boga (19,11-21).

\section{Posiadanie świadectwa Jezusa A TOŻSAMOŚĆ CHRZEŚCIJAŃSKA}

W świetle zaproponowanej analizy syntagmy „mieć świadectwo" wydaje się słuszna przywołana już wcześniej teza M. Marino, że wyraża ona ,głębszą tożsamość” wyznawców Jezusa. Chrześcijanie zostają scharakteryzowani w Apokalipsie właśnie jako ci, którzy „mają świadectwo Jezusa", to znaczy ich tożsamość jest kształtowana dzięki pamięci o Jezusie i wydarzeniach zbawczych, zwłaszcza

${ }^{51}$ Zob. Kotecki, Duch Święty, 345, 354, 454-455.

${ }^{52}$ Szerzej na ten temat, zob. Podeszwa, Paschalna, 108-131.

${ }^{53}$ Marino, Custodire, 123.

${ }^{54}$ Lampe, „The Testimony”, 254. 
Jego męce i zmartwychwstaniu ${ }^{55}$. Oznacza to, że świadectwo uczniów jest osadzone i budowane na fundamencie świadectwa, które sami otrzymali i któremu pozostają wierni. Jest to najpierw świadectwo samego Jezusa, który w misterium paschalnym objawił się „Swiadkiem Wiernym" $(1,5)$. Wydarzenie to przywoływane w pamięci i przeżywane w liturgii stanowi fundament świadectwa chrześcijańskiego. Przedmiotem tak pojmowanego świadectwa jest zatem zbawcza śmierć i zmartwychwstanie Jezusa. Misterium paschalne jest ,aktualizowane, rozpoznawane i proklamowane we wspólnocie (zgromadzeniu liturgicznym, które słucha słów księgi) dzięki Duchowi Świętemu, który mówi w prorokach" ${ }^{\text {"6 }}$. Uczeń Chrystusa nie może zapomnieć nigdy o tym, co stanowi fundament jego wiary i tożsamości jako wyznawcy Jezusa ${ }^{57}$. Utrata pamięci byłaby równoznaczna $z$ osłabieniem wiary, zaprzeczeniem nadziei, lękiem przed teraźniejszością i przyszłością ${ }^{58}$. Świadomość tych negatywnych konsekwencji utraty pamięci powinna być zachętą i przynagleniem dla wspólnoty Kościoła, aby pozostawała wierna „pamięci o Jezusie”. Jak słusznie zauważa ks. Hryniewicz: „W swojej głębokiej istocie chrześcijaństwo jest religią pamięci o Bogu i o człowieku. Pamięć o Bogu dotyczy przede wszystkim śladów Jego obecności i działania w dziejach ludzkości. Są to tak często dzieje cierpienia konkretnych ludzi, całych wspólnot, ludów i narodów. O cierpieniu tym nie wolno zapominać. Pamięć o cierpieniu jest istotnym elementem kultury duchowej, jaką niesie ze sobą chrześcijaństwo. Zachowuje ono nade wszystko pamięć o męce, śmierci krzyżowej i zmartwychwstaniu Chrystusa. Liturgiczna memoria passionis ma swoje uprzywilejowane miejsce w celebracji Eucharystii: „«To czyńcie na moją

${ }^{55}$ Zob. Podeszwa, Paschalna, 365-368.

${ }^{56}$ Kempiak, „Pneumatologia”, II, 157.

57 Przypomnijmy wymowny tytuł książki Jana Pawła II, Pamięć i tożsamość; zob. także Dziadowicz, „La mémoire”, 82-92.

${ }^{58} \mathrm{Na}$ te konsekwencje utraty pamięci zwraca uwagę Jan Paweł II, Ecclesia in Europa, $\mathrm{nr} 7$ (13) oraz $\mathrm{nr} 8$ (14). 
pamiątkę»" 59 . Należy zatem zgodzić się z R. Feuilletem, który twierdzi, że posiadanie świadectwa przez chrześcijan nie jest aktem, lecz stałym stanem uczniów Jezusa, który ich wprowadza w szczególną więź z Chrystusem ${ }^{60}$. Ta międzyosobowa relacja ${ }^{61}$ chrześcijan z Chrystusem i Bogiem Ojcem jest owocem wydarzenia paschalnego. To właśnie przelana na krzyżu krew Jezusa uczyniła z chrześcijan „królów, kapłanów” dla Boga $(1,6 ; 5,9)$. Dzięki misterium paschalnemu wyznawcy Jezusa mają możliwość „stać przed tronem Boga i przed Barankiem" (7,9), zwycięsko przechodząc przez uciski, wybielając szaty we krwi Baranka $(7,14)^{62}$, który jest ich Pasterzem $(7,17)$. Wydarzenie paschalne przyjęte $\mathrm{z}$ wiarą i przeżywane egzystencjalnie czyni z wyznawców Chrystusa Jego „wiernych świadków” na wzór Antypasa $(2,13)$, którzy „trzymają się imienia Jezusa i nie zaparli się wiary w Niego" $(2,13)$, jak chrześcijanie w Pergamonie ${ }^{63}$. Wierność świadectwu, które niesie w sobie pamięć o Passze Jezusa, pozwala im prorokować na wzór Dwóch Świadków $(11,3)$ oraz zwyciężać ,dzięki krwi Baranka i dzięki słowu swojego świadectwa" $(12,11)$ i stawać razem jako ,święci i świadkowie Jezusa", których krwią upija się Wielka Nierządnica $(17,6)$. To właśnie dzięki nieustannemu przywoływaniu w pamięci wydarzeń zbawczych chrześcijanie stają się wiernymi świadkami Jezusa, a ich świadectwo wobec świata jest autentyczne i pociągające przez fakt, że najpierw wiernie przechowują

${ }^{59}$ Hryniewicz, „Tożsamość chrześcijańska” http://www.opoka.org.pl/biblioteka/T/TE/konfesjonalizm_otwartosc.html\# [dostęp 18.06.2015].

${ }^{60}$ Zob. Feuillet, „Les martyrs”, 193.

${ }^{61}$ Szerzej na temat świadectwa, które ze swojej natury jest relacją między czterema osobami: tym, który wydaje świadectwo (podmiot świadectwa), tym, o kim wydaje się świadectwo (przedmiot świadectwa), tym, który powołuje się na świadectwo, oraz tym, przed kim świadek świadczy (odbiorca świadectwa), zob. Mickiewicz, Świadkowie, 23-26, 302-303.

${ }^{62}$ Zob. Podeszwa, „Wyprali swoje szaty”, 33-54.

${ }^{63}$ Zob. Podeszwa, ,Trwać przy Chrystusie”, 317-330; tenże, ,Antypas", 207-226. 
„świadectwo Jezusa" $(12,17 ; 19,10 ; 20,4)$, trwają mocno W wyznawaniu wiary $(2,13 ; 14,12)$, zachowują Jego słowo $(3,8)$ oraz publicznie wyznają Jego Imię $(2,13 ; 3,8)$, nawet za cenę własnego życia $(20,4)$. W ten sposób także chrześcijanie stają się świadkami i prorokami Jezusa $(10,7$; 11,3) wobec świata ${ }^{64}$.

Tożsamość chrześcijanina budowana na fundamencie aktywnej i dynamicznej pamięci o Jezusie, wydarzeniach zbawczych i człowieku zawsze powinna być otwarta na teraźniejszość i przyszłość jednocześnie. Bardzo trafnie ujmuje to ks. Hryniewicz: „Chrześcijańska tożsamość [...] kształtuje się $[\ldots]$ nie tylko w poczuciu wierności względem dziedzictwa otrzymanego od przeszłości (quod traditum est), ale również przez gotowość przyjęcia tego, co zostanie jeszcze odsłonięte i dane Kościołowi w przyszłości (quod dabitur). Nie na darmo mówił Chrystus w modlitwie arcykapłańskiej do Ojca wszystkich: «Objawiłem im Twoje imię i nadal będę objawiał» (J 17,26). O Duchu Świętym zapewniał: "On was wszystkiego nauczy i przypomni wam wszystko, co Ja wam powiedziałem» (J 14,26). Sama wierność wobec przeszłości prowadzi do fundamentalizmu i integryzmu, które wykluczają dary Boga w przyszłości. Samo otwarcie na przyszłość może rodzić niepewność i dezorientację. Łatwo zapomnieć wówczas o tym, co Bóg uczynił w przeszłości, i przeoczyć Jego dary już udzielone. Chrześcijańska kultura pamięci sięga w przeszłość i wybiega w przyszłość. Rany przeszłości leczy się po to, by kształtować nową przyszłość i nie powtarzać błędów przeszłości. Wymaga to ustawicznej dialektyki między przeszłością a przyszłością. Zapewnia ona tożsamości chrześcijańskiej właściwą jej dynamikę rozwoju i stawania się, zdolność do zmiany i otwartość względem przyszłości”" ${ }^{5}$. Tylko taka żywa i otwarta tożsamość wyznawców Chrystusa ma szansę ukształtować „świadków świadectwa"66 i wyrazić się w ich świadectwie,

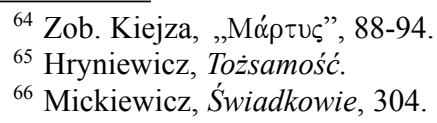


które będzie miało moc przemiany świata i pociągania innych do Boga, objawiającego się w Jezusie z Nazaretu.

\section{Podsumowanie}

Pierwsze błogosławieństwo Apokalipsy brzmi: ,Szczęśliwy, kto odczytuje, i ci, którzy słyszą słowa proroctwa oraz strzegą tego, co jest w nim napisane, bo czas jest bliski" $(1,3)$. Świadectwo chrześcijańskie winno zatem czerpać swoją moc z odczytywania, czyli nieustannego przywoływania w pamięci wydarzenia paschalnego, egzystencjalnego słuchania, które kształtuje życie oraz strzeżenia w sensie przestrzegania i zachowania go jako bezcennego daru przekazanego $\mathrm{w}$ depozycie apostolskim (1 Tm 6,20). Jednocześnie takie świadectwo chrześcijańskie ma być ukierunkowane ku światu, bo to właśnie chrześcijanie mają ujawnić światu tajemnice wiary i rzeczywistość zbawienia, dokonaną przez Boga w misterium paschalnym Chrystusa. Zadanie to będzie możliwe na tyle, na ile wyznawcy Jezusa będą świadomi posiadania Jego świadectwa, kształtującego ich tożsamość żywą i nieustannie otwierającą się na teraźniejszość oraz z nadzieją wychodzącą ku przyszłości. W ten sposób chrześcijanie staną się świadkami „wiary w Jezusa Chrystusa, źródło nadziei, która nie zawodzi”'67.

\section{Bibliografia}

Aune D.E., „The Prophetic Circle of John of Patmos and Exegesis of Revelation 22,16", Journal for the Study of the New Testament 37 (1989) 103-116.

Aune D.E., „The Social Matrix of the Apocalypse of John”, Biblical Research 26 (1981) 16-32.

Aune D.E., Revelation 1-5 (Nashville 1997).

Aune D.E., Revelation 6-16 (Nashville 1998).

${ }^{67}$ Jan Paweł II, Ecclesia in Europa, nr 18 (26). 
Aune D.E., Revelation 17-22 (Nashville 1998).

Beale G.K., The Book of Revelation (Grand Rapids 1999).

Beutler J., Martyria. Traditionsgeschichtliche Untersuchungen zum Zeugnisthema bei Johannes (Frankfurt am Main 1972). Bianchi M., „La testimonianza nella tradizione giovannea. Vangelo e Lettere", Testimonianza e verità. Un approccio interdisciplinare (red. P. Ciardella - M. Gronchi) (Roma 2000) 119-137.

Biguzzi G., ,John on Patmos and the «Persecution» in the Apocalypse”, Estudios Bíblicos 56 (1998) 201-220.

Biguzzi G., „Spirito e profezia nell'Apocalisse di Giovanni”, Estudios Bíblicos 60 (2002) 503-522.

Biguzzi G., L'Apocalisse e i suoi enigmi (Brescia 2004).

Boisacq É., Dictionnaire étymologique de la langue grecque étudiée dans ses rapports avec les autres langues indo-européennes (Heidelberg ${ }^{4} 1950$ ).

Bonsirven J., L'Apocalypse de Saint Jean (Paris 1951).

Caird G.B., A Commentary on the Revelation of St. John the Divine (London 1966).

Charles R.H., A Critical and Exegetical Commentary on the Revelation of St. John (Edinburgh 1920).

Coenen L., „Testimonianza $\mu \alpha \rho \tau u \rho i ́ \alpha ”$, Dizionario dei concetti biblici del Nuovo Testamento (red. A. Tessarolo) (Bologna 1976) $1857-1866$.

Contreras Molina F., „La mujer en Apocalipsis”, Ephemerides Mariologicae 43 (1993) 367-391.

Contreras Molina F., El Espíritu en el libro del Apocalipsis (Salamanca 1987).

Donegani I., „A cause de la parole de Dieu et du témoignage de Jésus...". Le témoignage selon l'Apocalypse de Jean (Paris 1997).

Dziadowicz A., „La mémoire - élément constitutif de l'identité.

Une approche biblique pour une culture en crise", Kultura - młodzież - edukacja (red. A. Popławska - L.M. Jakoniuk) (Białystok 2008) 82-92.

Dziewulski G., Świadectwo chrześcijańskie jako znak wiarygodności Kościoła (Lublin 2010)

Ernout A. - Meillet A., Dictionnaire étymologique de la langue latine (Paris $\left.{ }^{4} 1959\right)$. 
Farkaš P., La „Donna” di Apocalisse 12. Storia, bilancio, nuove prospettive (Roma 1997).

Feuillet A., „Les martyrs de l'humanité et l'Agneau égorgé. Une interprétation nouvelle de la prière des égorgés en Ap 6,9-11", Nouvelle Revue Théologique 99 (1977) 189-207.

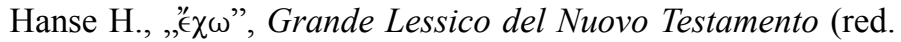
G. Kittel - G. Friedrich) (Brescia 1967) III, 1319-1351.

Hill D., „Prophecy and Prophets in the Revelation of St John”, New Testament Studies 18 (1971-1972) 401-417.

Hryniewicz W., ,Tożsamość chrześcijańska dzisiaj. Od konfesjonalizmu do tożsamości otwartej" http://www.opoka.org. $\mathrm{pl} /$ biblioteka/T/TE/konfesjonalizm_otwartosc.html\# [dostęp 20.12.2015].

Jan Paweł II, Ecclesia in Europa (Wrocław 2003).

Jan Paweł II, Pamięć i tożsamość (Kraków 2005).

Kempiak R., „Pneumatologia”, Teologia Nowego Testamentu.

II. Dzieło Janowe (red. M. Rosik) (Wrocław 2008) 83-158.

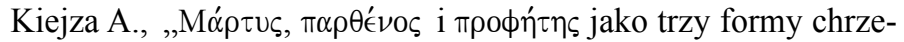
ścijańskiego świadectwa według Apokalipsy", Studia Franciszkańskie 10 (1999) 88-94.

Kotecki D., Duch Święty w zgromadzeniu liturgicznym w świetle Apokalipsy św. Jana (Warszawa 2006).

Kotecki D., Jezus a Bóg Izraela w Apokalipsie św. Jana (Toruń 2013).

Kudasiewicz J., ,Jeruzalem - punktem wyjścia misji apostolskiej (Łk 24,47n; Dz 1,8)", Materiały Kongresu Biblijnego w Krakowie, 6-8 czerwca 1972 r. (red. S. Grzybek - J. Chmiel) (Kraków 1974) 124-155.

Lampe G.W.H., „The Testimony of Jesus Is the Spirit of Prophecy (Rev 19:10)", The New Testament Age. Essays in Honour of Bo Reicke (red. W. Weinrich) (Leiden 1984) 254-258.

Le Grys A., „Conflict and Vengeance in the Book of Revelation", Expository Times 104 (1992) 76-80.

Léon-Dufour X., Lecture de l'Évangile selon Jean. II. Chapitres 5-12 (Paris 1990).

Luke K., „Biblijne pojęcie martyria ('swiadectwa)”, Ewangelizacja, dialog i rozwój (red. M. Dhavamony) (Warszawa 1986) 73-84. 
Malina A., „Imię «Jezus» w Ewangeliach”, Deus meus et omnia. Księga pamiątkowa ku czci o. prof. Hugolina Langkammera OFM w 50. rocznicę święceń kapłańskich (red. M.S. Wróbel) (Lublin 2005) 237-246.

Manzi F., Memoria del Risorto e testimonianza della Chiesa (Assisi 2006).

Marino M., Custodire la Parola. Il verbo $\tau \eta \rho \in \hat{\imath} \nu$ nell'Apocalisse alla luce della tradizione giovannea (Bologna 2003).

Mickiewicz F., Świadkowie zbawczego posłannictwa oraz mesjańskiej i boskiej godności Jezusa w pismach św. Łukasza iśw. Jana (Ząbki 2003).

Moriconi B., Lo Spirito e le Chiese. Saggio sul termine $\pi \nu \epsilon \hat{\nu} \mu \alpha$ nel libro dell'Apocalisse (Roma 1983).

Muszyński H., „Znak niewiasty według Apokalipsy”, U boku Syna. Studia z mariologii biblijnej (red. J. Szlaga ) (Lublin 1984) 115-127.

Oczachowski A., „,Dziecię, Niewiasta i Smok. Boży plan i dzieje człowieka na podstawie Apokalipsy św. Jana 12", Jak śmierć potężna jest miłość. Księga pamiątkowa ku czci księdza profesora Juliana Warzechy SAC (1944-2009) (red. W. Chrostowski) (Ząbki 2009) 307-331.

Podeszwa P., „Antypas - świadek wierny. Wiara chrześcijańska w świetle Ap 2,13", Świadkowie wiary. Biblia o wierze (red. D. Dziadosz) (Analecta Biblica Lublinensia 10; Lublin 2014) 207-226.

Podeszwa P., „Trwać przy Chrystusie i wiernie wyznawać Jego imię. Wiara chrześcijanina w świetle Ap 2,13”, Zawsze $z$ Tobą. Księga pamiątkowa ofiarowana biskupowi Zdzisławowi Fortuniakowi na pięćdziesięciolecie kapłaństwa (red. J. Hadryś) (Poznań 2013) 317-330.

Podeszwa P., ,Wyprali swoje szaty i wybielili je we krwi Baranka (Ap 7,14). Chrzest według Apokalipsy świętego Jana”, Studia Bydgoskie 7 (2013) 33-54.

Podeszwa P., Paschalna pamięć o Jezusie. Studium egzegetyczno-teologiczne wyrażenia $\dot{\eta} \mu \alpha \rho \tau v \rho i ́ \alpha$ 'I $\eta \sigma o \hat{v}$ w Apokalipsie św. Jana (Poznań 2011).

Popowski R., Wielki stownik grecko-polski Nowego Testamentu wydanie z petna lokalizacja haset, kluczem polsko-greckim oraz indeksem form czasownikowych (Warszawa 1995). 
Prigent P., Apocalypse 12. Histoire de l'exégèse (Tübingen 1959).

Prigent P., L'Apocalypse de Saint Jean (Genève 2000).

Pytel J.K., Apokalipsa świętego Jana Apostoła (Poznań 2008).

Rocci L., Vocabolario greco-italiano (Città di Castello $\left.{ }^{17} 1964\right)$.

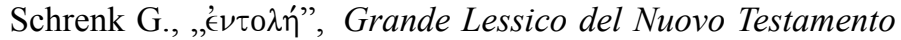
(red. G. Kittel - G. Friedrich) (Brescia 1967) III, 542-614. Schüssler Fiorenza E., „Apokalypsis and Propheteia. The Book of Revelation in the Context of Early Christian Prophecy", L'Apocalypse johannique et l'apocaliptique dans le Nouveau Testament (red. J. Lambrecht) (Leuven 1980) 105-128. Segalla G., „La memoria simbolica del Gesù terreno nel libro dell'Apocalisse", Liber Annuus 50 (2000) 115-141.

Sieg F., „Niewiasta” $i$,,Syn” w Apokalipsie św. Jana 12. Studium egzegetyczno-teologiczne (Warszawa 1987).

Smalley St.S., The Revelation to John. A Commentary on the Greek Text of the Apocalypse (Downers Grove 2005).

Stefaniak L., Interpretacja 12. rozdziatu Apokalipsy św. Jana $w$ świetle historii egzegezy (Poznań 1957).

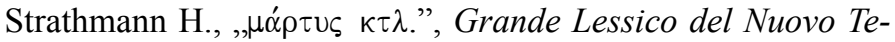
stamento (red. G. Kittel - G. Friedrich) (Brescia 1967) VI, 1269-1372.

Trites A.A., „M $\alpha \dot{\rho} \tau \cup \varsigma$ and Martyrdom in the Apocalypse. A Semantic Study", Novum Testamentum 15 (1973) 72-80.

Vos L.A., The Synoptic Traditions in the Apocalypse (Kampen 1965).

Wojciechowski M., Apokalipsa świętego Jana (Częstochowa 2012).

Zahn T., Die Offenbarung des Johannes (Leipzig 1924). 
Ks. Pawet Podeszwa

ul. Seminaryjna 2

62-200 Gniezno

paolop@poczta.onet.pl

Ks. Pawet Podeszwa, kapłan archidiecezji gnieźnieńskiej, doktor habilitowany nauk teologicznych, zatrudniony na stanowisku profesora nadzwyczajnego w Zakładzie Nauk Biblijnych Wydziału Teologicznego Uniwersytetu im. Adama Mickiewicza w Poznaniu. Należy do Stowarzyszenia Biblistów Polskich, Associazione Ex Alunni/e del Pontificio Istituto Biblico w Rzymie oraz pełni funkcję moderatora Dzieła Biblijnego im. Jana Pawła II w Archidiecezji Gnieźnieńskiej. Jest autorem ponad 50 artykułów z zakresu egzegezy i teologii biblijnej. Podejmuje wiele inicjatyw duszpasterskich, które służą popularyzacji orędzia biblijnego, a mianowicie Szkoły Słowa Bożego w Gnieźnie, Inowrocławiu, Wągrowcu, Żninie, Słupcy, Zagórowie, Kleczewie, Strzelnie, Trzemesznie; warsztaty i rekolekcje biblijne dla katechetów; konkursy biblijne; konferencje i wykłady w ramach Telewizyjnego Uniwersytetu Biblijnego w Telewizji ,Trwam” oraz w Radiu „Maryja”. 